\title{
KEGIATAN MENGALOKASIKAN DANA
}

\author{
PRESENTED BY: \\ ENNY WATI, SE., M.Si \\ ennywati75@gmail.com
}




\title{
Kegiatan Mengalokasikan Dana
}

\section{Pengertian Kredit Dan Pembiayaan}

\section{Unsur, Tujuan, Dan Fungsi Kredit}

Prinsip-prinsip Pemberian Kredit

\author{
Jenis Kredit
}

Perjanjian Dan Teknik Penyelesaian Kredit Macet 


\section{Kegiatan Mengalokasikan Dana}

- Alokasi dana adalah menjual kembali dana yang diperoleh dari penghimpunan dana dalam bentuk simpanan

- Alokasi dana bagi bank konvensional disebut kredit sedangkan untuk bank syariah disebut pembiayaan 


\section{Pengertian Kredit Dan Pembiayaan (UU No. 10/1998)}

Kredit adalah penyediaan uang atau tagihan yang dapat dipersamakan dengan itu berdasarkan persetujuan atau kesepakatan pinjam meminjam antar bank dengan pihak lain yang mewajibkan pihak peminjam melunasi utangnya setelah jangka waktu tertentu dengan pemberian bunga

Pembiayaan adalah penyediaan uang atau tagihan yang dapat dipersamakan dengan itu berdasarkan persetujuan atau kesepakatan pinjam meminjam antar bank dengan pihak lain yang mewajibkan pihak yang dibiayai untuk mengembalikan uang atau tagihan tersebut setelah jangka waktu tertentu dengan imbalan atau bagi hasil 


\section{Unsur, Tujuan, Dan Fungsi Kredit}

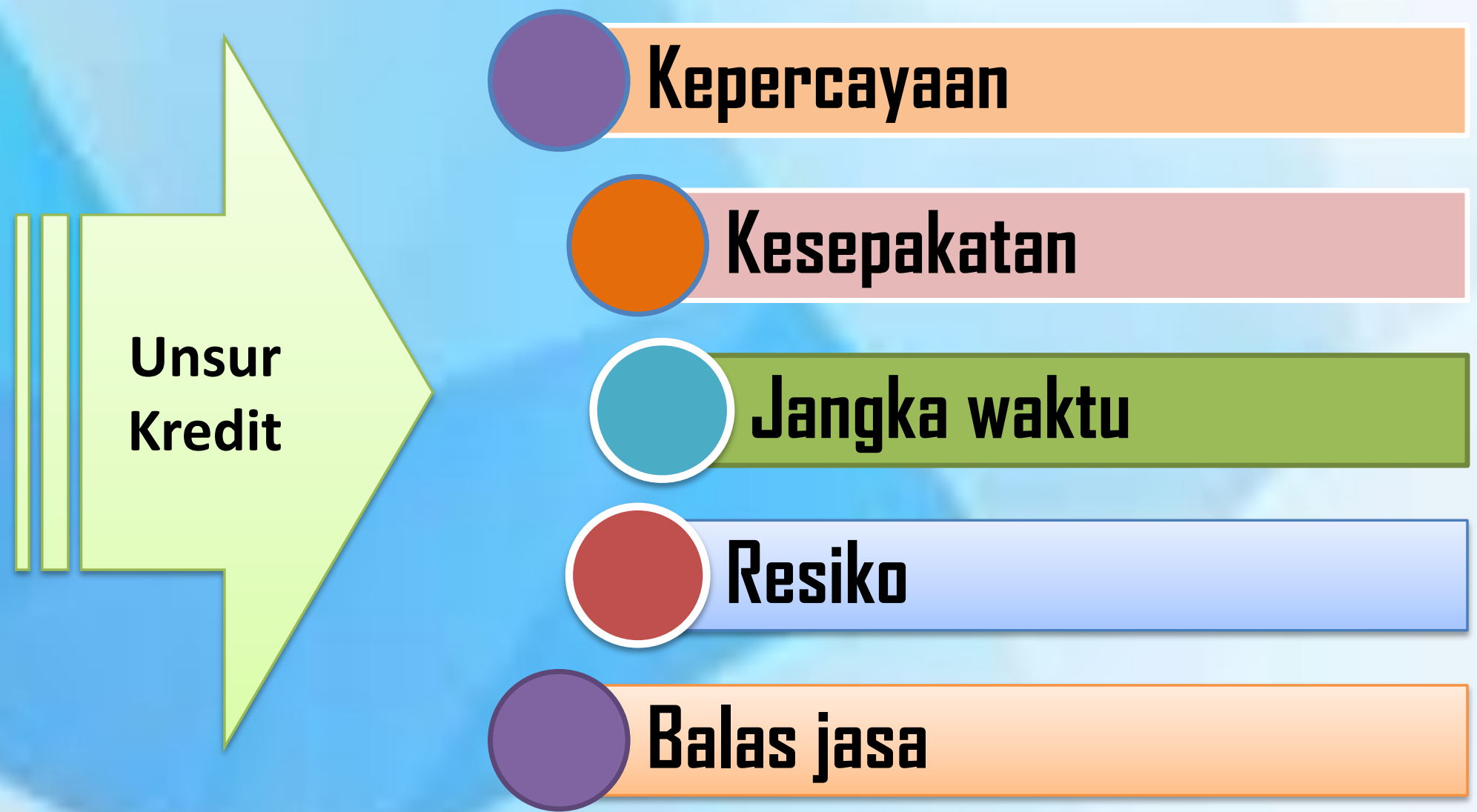




\section{Tujuan Kredit}

\section{Mencari keuntungan (bunga, by adm)}

\section{Membantu usaha nasabah}

\section{Membantu pemerintah}

\section{Penerimaan pajak}

Membuka kesempatan kerja

Meningkatkan jumlah barang dan jasa

Menghemat devisa (mepmproduksi barang imbor)

Meningkatkan deviso (mengekspor barang produksi) 


\section{Fungsi kredit}

- Meningkatkan daya guna uang

- Uang berguna untuk menghasilkan barang dan jasa

- meningkatkan peredaran dan lalulintas uang

- Meningkatkan daya guna barang

- Kredit yang diberikan dapat digunakan untuk merubah barang yang tdk berguna

- Meningkatkan peredaran barang

- Sebagai alat stabilitas ekonomi

- Untuk meningkatkan kegairahan bekerja

- meningkatkan pemerataan pendapatan

- Meningkatkan hubungan internasional 


\section{Prinsip-prinsip Pemberian Kredit}

Character

Capacity

Capital

Colleteral

Condition
Personality

Party

Purpose

Prospect

Payment

Profitability

Protection

Yuridis, pemasaran, keuangan, teknis/operasional, manajemen, sosial ekonomi, amdal 


\section{Jenis Kredit}

- Segi kegunaan

- Kredit investasi, Kredit modal kerja

- Segi tujuan

- k. Produktif, K. Konsumtif, K. Perdagangan

- Segi jangka waktu

- J. Pendek, J. Menengah, J. Panjang

- Segi jaminan

- Tanpa jaminan, Dengan jaminan (berwujud, tidak berwujud,orang)

- Dari sektor usaha

- Pertanian, peternakan, industri, pertambangan, pendidikan, profesi, perumahandll 


\section{Perjanjian Dan Teknik Penyelesaian Kredit}

Macet

\section{Prosedur Pemberian Kredit}

- Pengajuan berkas, Penyelidikan berkas, Wawancara 1, On the spot, Wawancara 2, Keputusan kredit, Penandatanganan akad kredit/perjanjian lainnya, Realisasi kredit, Penyaluran/penarikan dana

\section{Unsur terjadinya kredit macet}

Dari pihak perbankan, kurang teliti atau adanya kolusi , Pihak nasabah, unsur kesengajaan dan unsur ketidaksengajaan 


\section{Penyelamatan kredit macet}

- Rescheduling

- Memperpanjang jangka waktu kredit

- Memperpanjang jangka waktu angsuran

- Recnditioning

- Kapitalisasi bunga

- Penundaan pembayaran bunga sampai waktu tertentu

- penurunan suku bunga

- Pembebasan bunga

- Restructuring

- Menambah jumlah kredit

- Menambah equity (menyetor uang tunai/tambahan dari pemilik)

- Kombinasi

- Penyitaan jaminan 


\section{Sumber :}

Dr. Kasmir, SE.,MM, Bank dan Lembaga keuangan

lainnya, Edisi revisi ke-8, Penerbit Raja Grasindo Persada, Jakarta.2008. 
Thankyou 